\title{
A Dysregulation in CES1, APOE and Other Lipid Metabolism-Related Genes Is Associated to Cardiovascular Risk Factors Linked to Obesity
}

\author{
M. Pilar Marrades Pedro González-Muniesa J. Alfredo Martínez María J. Moreno-Aliaga
}

Department of Nutrition, Food Sciences, Physiology and Toxicology, University of Navarra, Pamplona, Spain

\section{Keywords}

Obesity · High-fat diet - Metabolic syndrome - CES1 . APOE · Lipid metabolism

\section{Summary}

Objective: The aim of the present study was to investigate the relationship between the differential expression of genes related to lipid metabolism in subcutaneous adipose tissue and metabolic syndrome features in lean and obese subjects with habitual high fat intake. Methods: Microarray and RT-PCR analysis were used to analyze and validate differential gene expression in subcutaneous abdominal adipose tissue samples from lean and obese phenotype subjects. Results: Several genes and transcripts involved in lipolysis were down-regulated, such as $A K A P 1, P R K A R 2 B$, Gi and CIDEA, whereas $N P Y 1 R$ and $C E S 1$ were up-regulated, when comparing obese to lean subjects. Similarly, transcripts associated with cholesterol and lipoprotein metabolism showed a differential expression, with $A P O E$ and $A B C A$ being decreased and $V L D L R$ being increased in obese versus lean subjects. In addition, positive correlations were found between different markers of the metabolic syndrome and CES1 and NPY1R mRNA expressions, while $A P O E$ showed an inverse association with some of them. Conclusion: Different expression patterns in transcripts encoding for proteins involved in lipolysis and lipoprotein metabolism were found between lean and obese subjects. Moreover, the dysregulation of genes such as CES 1 and APOE seems to be associated with some physiopathological markers of insulin resistance and cardiovascular risk factors in obesity.

\section{Introduction}

Adipose tissue plays a critical role in energy homeostasis by hydrolyzing triacylglycerol reserves to provide fatty acids, which are important oxidative fuels for other tissues in situations of energy demand such as fasting and exercise [1]. Thus, a fine regulation of lipolysis is crucial for the maintenance of body energy homeostasis as well as for the prevention of metabolic diseases. Indeed, excess fat accumulation is associated with a constellation of metabolic risk factors related to cardiovascular disease and type 2 diabetes, mainly due to a disproportionate release of fatty acids and an impairment in the secretion of adipokines [2]. On the other hand, lipodystrophy may also lead to physiopathological alterations often accompanying the metabolic syndrome [3]. The common link between both diseases may be a defective storage capacity in adipose tissue depots: in the case of lipodystrophy due to lack of proper amount of adipose tissue and in the case of obesity due to saturation of storage capacity [4]. Thus, the functional failure of the adipose tissue to buffer postprandial lipids due to a chronically disturbed energy balance could result in changes in adipokine secretion and vascular effects that influences the body homeostasis system, which has been proposed as an explanation of the metabolic syndrome [5]. Furthermore, variations in the nature and magnitude of the appearance of the metabolic syndrome manifestations are attributable to the interaction of genetic factors with environmental influences, most notably diet and physical activity $[6,7]$.

In this context, we investigated the relationship between the expression of several genes related to lipid metabolism and metabolic syndrome features in two phenotypically well characterized groups of subjects [8] that significantly differed with respect to body weight despite reporting similar daily fat intake and physical activity patterns; one group of volunteers remained lean and with no features of metabolic syndrome

\begin{tabular}{ll}
\hline KARGER & $\oplus$ 2010 S. Karger GmbH, Freiburg \\
Fax +497614520714 & Accessible online at: \\
Information@Karger.de & www.karger.com/ofa \\
www.karger.com &
\end{tabular}


and the other group was obese. Indeed, elucidating differences in gene expression in the subcutaneous abdominal adipose tissue (SCAAT) from these two groups of volunteers could help to develop therapies to prevent metabolic syndrome.

\section{Subjects and Methods}

\section{Study Design and Subjects}

Nine lean (22-33 years old) and 9 age-matched obese high-fat consumers (21-35 years old) were recruited as previously described, using a validated questionnaire based on self-reported questions about lifestyle and food frequency consumption [8]. All subjects were healthy, non-diabetic, non-hyperlipidemic males taking no oral medications and showing a stable body weight during at least the previous 3 months. In order to confirm that the amount and composition of energy ingested was $>40 \%$ from fat, each subject completed a 3-day weighed food record for 2 weekdays and 1 weekend day. The food records were analyzed by a trained nutritionist using a computerized program (Medisystem, SanoCare, Madrid, Spain). To quantify the level of physical activity, each participant completed a validated questionnaire [9] based on self-reported questions about their leisure time and their work time physical activities on a typical workday and on a typical weekend day. In addition, sedentary lifestyle was assessed through the number of hours per week spent sitting down (watching TV or videos, reading or listening to music, etc.) on a typical workday and on a typical weekend day. All volunteers remained living in the same conditions during at least the last 3 years.

Anthropometrical Measurements and Adipose Tissue Biopsy

On the experimental day, volunteers arrived at the Clinica Universidad de Navarra after $12 \mathrm{~h}$ of overnight fast. Anthropometrical measurements were made using standard procedures as previously described [8]. Then, biopsies of SCAAT (1-2 g) were performed by liposuction under local anesthesia. The samples were washed and soaked in RNA-later (Qiagen, Valencia, CA, USA) to avoid RNA degradation and then stored at $-80{ }^{\circ} \mathrm{C}$ until utilization. The protocol was approved by the Ethical Committee of the University of Navarra meeting the standards of the Declaration of Helsinki [10], and all subjects gave their written informed consent before participating in the study.

\section{Blood Pressure and Measurements}

Blood pressure (systolic and diastolic) was measured with a standard mercury sphygmomanometer (Minimus II, Riester, Jungingen, Germany) after the subject was quietly sitting for $5 \mathrm{~min}$ following WHO criteria. Fasting blood measurements were made by standard procedures as previously described [8]. The quantitative insulin sensitivity check index (QUICKI) was determined using the inverse of the sum of the logarithms of the fasting insulin $(\mu \mathrm{U} / \mathrm{ml})$ and fasting glucose $(\mathrm{mg} / \mathrm{dl})$.

\section{RNA Preparation}

Total RNA was isolated from each human SCAAT sample (including adipocytes and stroma-vascular fraction) by homogenization with an ultra-turrax ${ }^{\circledR}$ T 25 basic using TRIzol (Life Technologies, Gaithersburg, MD, USA) according to the manufacturer's instructions and incubated with RNase-free DNase (Ambion, Austin, TX, USA) for $30 \mathrm{~min}$ at $37^{\circ} \mathrm{C}$. RNA concentration was measured spectrophotometrically, and its quality was verified by ethidium bromide staining after agarose gel electrophoresis.

Microarray Experiments and Analysis

RNA was pooled to minimize the biological variation between the individual lean and obese subjects. Thus, $15 \mu \mathrm{g}$ of total RNA from two pools of 3 lean subjects each (L1 and L2) and two other from 3 obese individuals each (O1 and $\mathrm{O} 2)$ were used in the standard protocol from Affymetrix to label targets. These targets (biotinylated complementary RNA) were hybridized to the Human HG-U133 A GeneChip arrays (Affymetrix; Santa Clara, CA, USA) at Progenika Biopharma Inc. (DerioVizcaya, Spain), using tools obtained from Affymetrix and according to the manufacturer's protocol (Affymetrix). Thus, a total of 4 array hybridizations were performed. The obtained signal values were further analyzed with the Affymetrix microarray suite 5.0. software (MAS 5.0) system to examine obesity-dependent increases and decreases in gene expression. After global scaling, the signal detection, the signal log ratio (SLR) and the different call change were calculated and compared between GeneChips. The comparison was performed for all four combinations: obese versus lean samples; $\mathrm{O} 1$ versus $\mathrm{L} 1, \mathrm{O} 1$ versus $\mathrm{L} 2$; $\mathrm{O} 2$ versus L1; O2 versus L2 in a double-cross analysis (concordance analysis). The alteration ratios of the gene expression were represented as means of SLR of the four quotients [11].

GARBAN software $[12,13]$ was used to classify the differentially expressed genes according to Gene Ontology biological process criteria.

\section{Real-Time PCR Analysis}

Differential gene expression was further confirmed by real-time PCR of a subset of genes in individual samples ( $\mathrm{n}=9$ in each group). Reagents for real-time PCR analysis of AKAP1, NPY1R, CES1, APOE, VLDLR and $18 S$ (Assays-on-Demand, TaqMan Reverse Transcriptase reagents, and TaqMan Universal PCR Master mix) were purchased from Applied Biosystems (Foster City, CA, USA) and used according to the manufacturer's protocol. Amplification and detection of specific products were performed with the ABI PRISM 7000HT system (Applied Biosystems). Human $18 S$ was used as reference to normalize the expression levels between samples, allowing data to be expressed relative to $18 \mathrm{~S}$ rRNA and thus compensating for any differences in reverse transcriptase efficacy, as previously described [11].

\section{Statistical Analysis}

Data are expressed as means $\pm \mathrm{SE}$ ( $\mathrm{n}=9$ in each group). Differences between the lean and obese groups were analyzed by the unpaired Student's $\mathrm{t}$ test or Mann-Whitney U test after testing the normality with the Kolmogorov-Smirnoff and Shapiro-Wilk tests, and Pearson and Spearman correlation coefficients were used to identify related variables. A p value $<0.05$ was considered statistically significant. The SPSS 14.0 version for Windows (SPSS, Chicago, IL, USA) was used for the statistical analysis.

\section{Results}

\section{Baseline Characteristics of Lean and Obese Subjects}

Not surprisingly with respect to the study design, BMI, waist circumference and waist-to-height ratio were significantly higher in obese than in lean subjects. Insulin sensitivity revealed by QUICKI was significantly lower in obese compared to lean subjects. The fasting lipid profile, including triglycerides, total cholesterol and total / high-density lipoprotein (HDL) cholesterol ratio, was significantly higher in obese than in lean participants. The systolic and diastolic blood pressure values were significantly elevated in obese when compared to lean subjects. Moreover, the amount of leptin in blood was higher in obese subjects, while adiponectin was lower (table 1). Even though high-fat diet is associated with presence of the metabolic syndrome, lean volunteers showed no features of metabolic syndrome. According to the National 
Table 1. Anthropometrical and clinical parameters of volunteers ${ }^{\mathrm{a}}$

\begin{tabular}{lccl}
\hline & Lean $(\mathrm{n}=9)$ & Obese $(\mathrm{n}=9)$ & $\mathrm{p}$ \\
\hline Energy intake, kcal/day & $2,766.7 \pm 258.7$ & $2,799.1 \pm 171.4$ & 0.918 \\
BMI, kg/m ${ }^{2}$ & $23.1 \pm 0.4$ & $34.7 \pm 1.2$ & 0.000 \\
Waist circumference, cm & $78.7 \pm 1.2$ & $105.7 \pm 2.6$ & 0.000 \\
Waist/height ratio & $0.45 \pm 0.01$ & $0.60 \pm 0.01$ & 0.000 \\
Leptin, $\mathrm{ng} / \mathrm{ml}$ & $8.3 \pm 2.6$ & $33.3 \pm 4.6$ & 0.000 \\
Adiponectin, $\mu \mathrm{gg} / \mathrm{ml}$ & $20.1 \pm 3.3$ & $10.0 \pm 1.7$ & 0.037 \\
Glucose, $\mathrm{mg} / \mathrm{dl}$ & $90.3 \pm 3.9$ & $92.7 \pm 2.3$ & 0.070 \\
QUICKI & $0.40 \pm 0.00$ & $0.35 \pm 0.01$ & 0.004 \\
Triglycerides, $\mathrm{mg} / \mathrm{dl}$ & $85.0 \pm 6.7$ & $142.2 \pm 10.6$ & 0.001 \\
Total cholesterol, mg/dl & $167.4 \pm 17.7$ & $188.5 \pm 6.3$ & 0.008 \\
HDL cholesterol, mg/dl & $43.3 \pm 1.7$ & $40.0 \pm 2.4$ & 0.059 \\
Total/HDL cholesterol ratio & $3.5 \pm 0.2$ & $5.0 \pm 0.3$ & 0.003 \\
SBP, $\mathrm{mm} \mathrm{Hg}$ & $122.5 \pm 3.6$ & $139.1 \pm 2.8$ & 0.002 \\
DBP, mm Hg & $74.0 \pm 2.2$ & $82.8 \pm 3.0$ & 0.002 \\
\hline
\end{tabular}

$\mathrm{HDL}=$ high-density lipoprotein; $\mathrm{LDL}=$ low-density lipoprotein;

QUICKI = quantitative insulin-sensitivity check index; SBP = systolic blood pressure;

$\mathrm{DBP}=$ diastolic blood pressure.

${ }^{a}$ Values are means \pm S.E.M. Independent Student's t-test or Mann-Whitney U-test was performed, as appropriate, depending on the results of Kolmogorov-Smirnoff and Shapiro-Wilk normality tests.
Table 2. Differentially expressed genes involved in lipid and cholesterol metabolism in SCAAT of obese vs lean subjects
Cholesterol Education Program, 5 of the obese volunteers were considered obese with metabolic syndrome based on the presence of three or more of the following characteristics: waist circumference greater than $102 \mathrm{~cm}$, blood pressure of at least 130/85 mm Hg, serum glucose level of at least $110 \mathrm{mg} / \mathrm{dl}$, serum triacylglycerol level of at least $150 \mathrm{mg} / \mathrm{dl}$ and HDL cholesterol level of less than $40 \mathrm{mg} / \mathrm{dl}$.

\section{Microarray Data}

The analysis of the microarray data revealed that several relevant transcripts involved in lipid metabolism were differentially expressed in SCAAT of obese and lean subjects (table 2). Some genes involved in the hormonally regulated lipolysis - AKAP1, PRKAR2B - were down-regulated, whereas $N P Y 1 R$ was up-regulated (table 2). As expected, 
Table 3. Correlation between gene expression and metabolic syndrome features ${ }^{\mathrm{a}}$

\begin{tabular}{|c|c|c|c|c|c|c|}
\hline & \multicolumn{2}{|c|}{$A P O E$} & \multicolumn{2}{|l|}{ CES1 } & \multicolumn{2}{|c|}{$N P Y 1 R$} \\
\hline & $\mathrm{r}$ & $\mathrm{p}$ & $\mathrm{r}$ & $\mathrm{p}$ & $\mathrm{r}$ & $\mathrm{p}$ \\
\hline $\mathrm{BMI}, \mathrm{kg} / \mathrm{m}^{2}$ & -0.68 & 0.006 & 0.43 & 0.114 & 0.30 & 0.272 \\
\hline Waist circumference, $\mathrm{cm}$ & -0.61 & 0.015 & 0.55 & 0.032 & 0.65 & 0.009 \\
\hline Waist/height ratio & -0.58 & 0.023 & 0.53 & 0.044 & 0.55 & 0.035 \\
\hline Leptin, ng/ml & -0.56 & 0.030 & 0.31 & 0.262 & 0.36 & 0.191 \\
\hline Adiponectin, $\mu \mathrm{g} / \mathrm{ml}$ & 0.52 & 0.049 & -0.16 & 0.568 & 0.30 & 0.282 \\
\hline Glucose, $\mathrm{mg} / \mathrm{dl}$ & -0.46 & 0.088 & 0.55 & 0.035 & 0.30 & 0.275 \\
\hline Triglycerides, mg/dl & -0.40 & 0.139 & 0.73 & 0.002 & 0.34 & 0.218 \\
\hline Total/HDL cholesterol ratio & -0.65 & 0.009 & 0.65 & 0.009 & 0.52 & 0.048 \\
\hline
\end{tabular}

${ }^{a}$ Pearson and Spearman correlations were performed between gene expression (arbitary units $2^{-\Delta \Delta C t}$ ) and other parameters. several transcripts related to TNF- $\alpha$-induced lipolysis were down-regulated including $G i$ and $C I D E A$. In contrast, $C E S 1$, an adipocyte lipase involved in basal lipolysis, was up-regulated (table 2).

In addition, several transcripts involved in cholesterol and lipoprotein metabolism, e.g. $A P O E$ and $A B C A$, a cellular cholesterol transporter, were down-regulated (table 2) while $V L D L R$ was up-regulated in SCAAT in the obese subjects (table 2).

$m R N A$ Expression of Selected Genes Correlated with Several Features of the Metabolic Syndrome

Gene expression of CES1, NPY1R, AKAP1, VLDLR and $A P O E$ was analyzed for potential association with different cardiovascular risk markers (table 3). A positive correlation was found between CES1 mRNA expression in SCAAT and waist circumference $(\mathrm{r}=0.55 ; \mathrm{p}=0.032)$ and the waist-toheight ratio $(\mathrm{r}=0.53 ; \mathrm{p}=0.044)$. Also, CES1 mRNA levels correlated with plasma glucose $(\mathrm{r}=0.55 ; \mathrm{p}=0.035)$ and triglyceride levels $(\mathrm{r}=0.73 ; \mathrm{p}=0.002)$ and with the cardiovascular risk factor total/HDL cholesterol $(\mathrm{r}=0.65 ; \mathrm{p}=0.009)$. A positive correlation was found between NPY1R mRNA expression in SCAAT and waist circumference $(\mathrm{r}=0.65 ; \mathrm{p}=0.009)$ and the waist-to-height ratio $(\mathrm{r}=0.55 ; \mathrm{p}=0.035)$. Moreover, $N P Y 1 R$ mRNA levels were associated with the cardiovascular risk index $(\mathrm{r}=0.52 ; \mathrm{p}=0.048)$.

Negative correlations were found between $A P O E$ mRNA expression in SCAAT and BMI $(\mathrm{r}=-0.68 ; \mathrm{p}=0.006)$, waist circumference $(\mathrm{r}=-0.61 ; \mathrm{p}=0.015)$ as well as waist-to-height ratio $(\mathrm{r}=-0.58 ; \mathrm{p}=0.023)$. APOE was negatively correlated with leptin $(\mathrm{r}=-0.56 ; \mathrm{p}=0.030)$ and positively correlated with adiponectin $(\mathrm{r}=0.52 ; \mathrm{p}=0.049)$. Moreover, APOE mRNA levels were inversely correlated with the cardiovascular risk index $(\mathrm{r}=-0.65 ; \mathrm{p}=0.009)$ (table 3$)$ and also with diastolic blood pressure $(\mathrm{r}=-0.62 ; \mathrm{p}=0.014)$.

$A K A P 1$ mRNA levels were only significantly correlated with the waist-to-height ratio $(-0.59 ; \mathrm{p}=0.016)$ while no significant associations were found between $V L D L R$ mRNA levels and metabolic syndrome features.

\section{Discussion}

In the present study, mRNA expression differences of genes related to lipid and cholesterol metabolism between obese and lean subjects with habitual high-fat diet and physical activity, otherwise phenotypically well characterized [8], were investigated. The analysis of anthropometrical and clinical variables of the obese subjects suggest that they have a higher risk for developing insulin resistance, hyperlipidemia and cardiovascular disease, which are typical features of the metabolic syndrome. Indeed, 5 of the obese subjects investigated could be diagnosed with metabolic syndrome according to Adult Treatment Panel III and World Health Organization criteria [6]. However, new criteria are under discussion [14] and may change the assignment. The mechanisms underlying the metabolic syndrome are not well understood. Current evidence supports that the accumulation of abdominal fat is a major determinant of the metabolic syndrome, while gluteofemoral body fat seems to exert a protective role [15]. Upper-body subcutaneous fat is the dominant contributor to circulating free fatty acids and the main source of excess fatty acid release in upper-body obesity and of abnormalities in subcutaneous lipolysis, which appears to be an important cause of peripheral insulin resistance [16], possibly through altering fat storage and the expression of TNF- $\alpha$ by adipocytes in visceral fat [17]. We investigated the differential expression of genes encoding proteins participating in lipid and lipoprotein metabolism in adipose tissue. The microarray analysis revealed that several transcripts involved in the stimulation of lipolytic pathway were down-regulated in obese but not in lean subjects. Among them is the regulatory subunit type II $\beta$ of PKA (PRKAR2B) which plays a crucial and central role in the regulation of energy expenditure and glucose and lipid metabolism $[18,19]$. Its activity is known to be modulated by its specific location in the cell, a process mediated by A-kinase anchoring proteins (AKAPs) [20]. In fact, $A K A P 1$, identified as a major adipocyte protein kinase Abinding protein [21], was down-regulated in obese subjects. We also found that the transcription of $N P Y 1 R$, a powerful 
antilipolytic agent [22], was up-regulated in SCAAT of obese patients, which is in accordance with a previous study where a similar up-regulation was found in omental adipose tissue [23]. These data agree with those of several studies, which have shown that obesity is associated with an impaired catecholamine-induced lipolysis and a reduced HSL and ATGL expression in adipocytes [24, 25]. However, elevated basal lipolysis has been observed in obese individuals which is related to the bigger fat cell size and to increased levels of proinflammatory cytokines in adipose tissue [26, 27].

Moreover, in our study a down-regulation of Gi $\alpha$ and $C I D E A$ in obese subjects was found. CIDEA has been assumed to have a specific role in lipolysis in white human fat cells mediated by cross-talk with TNF- $\alpha$ [28]. Thus, the elevated basal lipolysis observed in obesity implies that other TG lipases may be up-regulated. Our study revealed that the adipocyte lipase carboxylesterase 1 (CES1) an orthologue of carboxylesterase 3 (also named $T G H 2$ ), which was first described by Soni et al [29], was up-regulated in obese subjects, which is in agreement with other studies [30, 31]. This lipase is highly expressed in adipocytes and is transcriptionally regulated in response to changes in nutritional conditions, suggesting a relevant role in lipolytic response to extended fasting in adipocytes [32]. In our study, the positive association between CES1 and obesity was further supported by the fact that CES1 mRNA expression was positively correlated with waist circumference, a recognized marker of adiposity and dyslipidemia [33], and with the waist-to-height ratio, a useful predictor of coronary heart disease risk factor [34]. In addition, the positive correlation between CES1 mRNA expression and total/HDL cholesterol ratio, a known factor for cardiovascular risk, suggests that CES1 could play a role in the impaired basal lipolysis in SCAAT from obese individuals. However, a recent publication has found no correlation between CES1 expression and lipolytic activity in isolated human adipocytes [31].

On the other hand, the impaired capacity for the sensing of the replenishment of their lipid stores by adipocytes which results in alterations in the buffering capacity of adipose tissue has been suggested as the cause of metabolic syndrome [5, 35 . Based on the fact that triacylglycerol and cholesterol storage are closely linked in adipocytes, it has been postulated that cholesterol might participate in the intracellular sensing for fat cell size and triacylglycerol content $[36,37]$. Our microarray and RT-PCR analysis showed a down-regulation of the $A P O E$ gene in obese subjects. This is in accordance with the marked suppression of adipose APOE observed in both dietinduced and genetic (ob/ob mice) models of obesity [38]. A recent study evidenced that excess fat accumulation via an APOE-dependent pathway might play a role in development of the metabolic syndrome [39]. APOE is secreted by cells with high lipid efflux, and it has been shown to be expressed highly in adipose tissue $[40,41]$. In these cells, APOE modulates cellular cholesterol metabolism by facilitating choles- terol transfer. In fact, the study of Huang et al. [38] suggested that these changes in adipose tissue $A P O E$ expression have significant impact on adipose tissue lipid flux and lipoprotein metabolism [38]. These data and our present observations in human adipose tissue suggest that adipose APOE may participate in defending adipose tissue and organismal energy homeostasis in response to high fat feeding. In contrast to $A P O E$, $V L D L R$, another gene related with cholesterol transport, was up-regulated. It is well known that high levels of plasma VLDL are associated with obesity, type 2 diabetes [42, 43] and cardiovascular disease [44]. Moreover, VLDLR can play a role in the delivery of VLDL-TG-derived free fatty acids to adipose tissue, modulating circulating levels of TG and VLDL $[45,46]$. Indeed, $V L D L R-/-$ mice were protected from highfat diet-induced obesity showing a decreased adipocyte size [47] and triglyceride storage in the adipocyte compared to wild-type counterparts $[46,48]$. Interestingly, a positive correlation between CES1 and VLDLR mRNA levels was found (data not shown).

In the present study, whole adipose tissue was used for gene expression profile analysis, even if this tissue only provides a mixture of cells (stroma-vascular cells and adipocytes). An interesting question to be answered is which of these cell fractions are mainly contributing to the observed gene expression changes in adipose tissue. Regarding CES1, several previous studies have observed that CES1 expression is higher in isolated adipocytes compared to intact adipose tissue [31]. Previous studies have also shown that $A P O E$ mRNA is found in differentiated 3T3-L1 adipocytes as well as in biopsies of human adipose tissue, but not in undifferentitated 3T3-L1 adipocytes [49], suggesting that the main contribution in $A P O E$ gene expression observed in adipose tissue from obese subjects could come from the adipocytes. However, another study described that $A P O E$ is also down-regulated in adipose tissue-recruited macrophages during high-fat diet when compared with resident macrophages [50]. In any case, it is important to emphasize that information obtained about differential gene expression from the tissue as a whole is relevant. Indeed, total adipose tissue has been widely used to identify genes associated with obesity using DNA microarrays [51, 52].

During the last years many efforts have been made to define and search for genes associated with obesity and metabolic syndrome. In this context, several studies have aimed to look for genes differentially expressed in adipose tissue from lean and obese subjects $[23,53]$. The main novelty of the present study arise from the fact that it was designed to look for adipose tissue genes conferring susceptibility or resistance to develop obesity and metabolic syndrome in two well characterized groups of subjects. Despite living in same environmental conditions (habitual high fat dietary intake and similar moderate physical activity), one group was resistant to gain weight and to develop metabolic syndrome features, while the other was susceptible to develop obesity and its associated metabolic complications. 
In summary, our data show a different expression of adipose transcripts encoding for proteins involved in lipolysis and lipoprotein metabolism in subjects 'resistant' or 'susceptible' to develop high-fat diet-induced obesity. These results, taken as a whole, suggest that the changes in the expression levels of these adipose tissue genes may have significant impact on adipose tissue lipolysis rate as well as on lipid flux and lipoprotein metabolism. Nevertheless, the molecular mechanisms underlying the control of these key lipid metabolism processes are still not fully understood. Our data also suggest that CES1, a recently discovered lipase, and APOE could play a role in obesity-associated cardiovascular risk factors and might be promising targets in metabolic syndrome treatment.

\section{Acknowledgements}

We are grateful to Ms. Veronica Ciaurriz for her help; we also gratefully acknowledge the receipt of funding from the Government of Navarra (Health Department) and the Linea Especial of the University of Navarra (LE/97).

\section{Disclosure}

The authors declared no conflict of interest.

\section{References}

1 Watt MJ, Spriet LL: Triacylglycerol lipases and metabolic control: implications for health and disease. Am J Physiol 2010;299:E162-168.

$\checkmark 2$ Westphal SA: Obesity, abdominal obesity, and insulin resistance. Clin Cornerstone 2008;9:23-29; discussion 30-21.

$\checkmark 3$ Oral EA, Chan JL: Rationale for leptin-replacement therapy for severe lipodystrophy. Endocr Pract 2010:16:324-333.

4 Frayn KN: Adipose tissue as a buffer for daily lipid flux. Diabetologia 2002;45:1201-1210.

5 Laclaustra M, Corella D, Ordovas JM: Metabolic syndrome pathophysiology: the role of adipose tissue. Nutr Metab Cardiovasc Dis 2007;17:125-139.

6 Grundy SM: Metabolic syndrome: connecting and reconciling cardiovascular and diabetes worlds. J Am Coll Cardiol 2006;47:1093-1100.

7 Lawson HA, Cheverud JM: Metabolic syndrome components in murine models. Endocr Metab Immune Disord Drug Targets 2010;10:25-40.

8 Marrades MP, Martinez JA, Moreno-Aliaga MJ: Differences in short-term metabolic responses to a lipid load in lean (resistant) vs obese (susceptible) young male subjects with habitual high-fat consumption. Eur J Clin Nutr 2007;61:166-174.

$\checkmark 9$ Martinez-Gonzalez MA, Lopez-Fontana C, Varo JJ, Sanchez-Villegas A, Martinez JA: Validation of the Spanish version of the physical activity questionnaire used in the nurses' health study and the health professionals' follow-up study. Public Health Nutr 2005;8:920-927.

10 World Medical Association Declaration of Helsinki: Recommendations guiding physicians in biomedical research involving human subjects. JAMA 1997;277:925-926.

11 Marrades MP, Milagro FI, Martinez JA, MorenoAliaga MJ: Differential expression of aquaporin 7 in adipose tissue of lean and obese high fat consumers. Biochem Biophys Res Commun 2006;339: 785-789.

12 Martinez-Cruz LA, Rubio A, Martinez-Chantar ML, Labarga A, Barrio I, Podhorski A, Segura V, Sevilla Campo JL, Avila MA, Mato JM: Garban: Genomic analysis and rapid biological annotation of cDNA microarray and proteomic data. Bioinformatics 2003;19:2158-2160.

-13 Segura V, Podhorski A, Guruceaga E, Sevilla JL, Corrales FJ, Rubio A: Garban II: an integrative framework for extracting biological information from proteomic and genomic data. Proteomics 2006;6(suppl 1):S12-15.
14 Alberti KG, Eckel RH, Grundy SM, Zimmet PZ, Cleeman JI, Donato KA, Fruchart JC, James WP, Loria CM, Smith SC Jr: Harmonizing the metabolic syndrome: a joint interim statement of the International Diabetes Federation Task Force on epidemiology and prevention; National Heart, Lung, And Blood Institute; American Heart Association; World Heart Federation; International Atherosclerosis Society; and International Association For The Study Of Obesity. Circulation 2009; 120:1640-1645.

15 Manolopoulos KN, Karpe F, Frayn KN: Gluteofemoral body fat as a determinant of metabolic health. Int J Obes (Lond) 2010;34:949-959.

16 Alibegovic AC, Hojbjerre L, Sonne M, Hall GV, Alsted TJ, Kiens B, Stallknecht B, Dela F, Vaag A: Increased rate of whole body lipolysis before and after nine days of bed rest in healthy young men born with low birth weight. Am J Physiol Endocrinol Metab 2010;298:E555-564.

17 Ishikawa K, Takahashi K, Bujo H, Hashimoto N, Yagui K, Saito Y: Subcutaneous fat modulates insulin sensitivity in mice by regulating TNF-alpha expression in visceral fat. Horm Metab Res 2006;38: 631-638.

18 Newhall KJ, Cummings DE, Nolan MA, McKnight GS: Deletion of the RIIbeta-subunit of protein kinase A decreases body weight and increases energy expenditure in the obese, leptin-deficient ob/ob mouse. Mol Endocrinol (Baltimore) 2005;19:982-991.

19 Planas JV, Cummings DE, Idzerda RL, McKnight GS: Mutation of the RIIbeta subunit of protein kinase A differentially affects lipolysis but not gene induction in white adipose tissue. J Biol Chem 1999;274:36281-36287.

20 Carnegie GK, Smith FD, McConnachie G, Langeberg LK, Scott JD: AKAP-lbc nucleates a protein kinase D activation scaffold. Mol Cell 2004;15:889-899.

21 Bridges D, MacDonald JA, Wadzinski B, Moorhead GBG: Identification and characterization of D-AKAP1 as a major adipocyte PKA and PP1 binding protein. Biochem Biophys Res Commun 2006;346:351-357.

22 Margareto J, Aguado M, Oses-Prieto JA, Rivero I, Monge A, Aldana I, Marti A, Martinez JA: A new NPY-antagonist strongly stimulates apoptosis and lipolysis on white adipocytes in an obesity model. Life Sci 2000;68:99-107.
23 Gomez-Ambrosi J, Catalan V, Diez-Caballero A, Martinez-Cruz LA, Gil MJ, Garcia-Foncillas J, Cienfuegos JA, Salvador J, Mato JM, Fruhbeck G: Gene expression profile of omental adipose tissue in human obesity. FASEB J 2004;18:215-217.

24 Large V, Peroni O, Letexier D, Ray H, Beylot M: Metabolism of lipids in human white adipocyte. Diabetes Metab 2004:30:294-309.

25 Jocken JWE, Langin D, Smit E, Saris WHM, Valle C, Hul GB, Holm C, Arner P, Blaak EE: Adipose triglyceride lipase (ATGL) and hormone-sensitive lipase (HSL) protein expression is decreased in the obese insulin resistant state. J Clin Endocrinol Metab 2007;92:2292-2299.

26 Viguerie N, Vidal H, Arner P, Holst C, Verdich C, Avizou S, Astrup A, Saris WH, Macdonald IA, Klimcakova E, Clement K, Martinez A, Hoffstedt J, Sorensen TI, Langin D: Adipose tissue gene expression in obese subjects during low-fat and highfat hypocaloric diets. Diabetologia 2005;48:123-131.

27 Langin D, Arner P: Importance of TNFalpha and neutral lipases in human adipose tissue lipolysis. Trends Endocrinol Metabolism 2006;17:314-320.

28 Nordstrom EA, Ryden M, Backlund EC, Dahlman I, Kaaman M, Blomqvist L, Cannon B, Nedergaard J, Arner P: A human-specific role of cell death-inducing DFFA (DNA fragmentation factor-\{alpha\})-like effector a (CIDEA) in adipocyte lipolysis and obesity. Diabetes 2005;54:1726-1734.

29 Soni KG, Lehner R, Metalnikov P, O’Donnell P, Semache M, Gao W, Ashman K, Pshezhetsky AV, Mitchell GA: Carboxylesterase 3 (EC 3.1.1.1) is a major adipocyte lipase. J Biol Chem 2004;279: 40683-40689.

-30 Steinberg GR, Kemp BE, Watt MJ: Adipocyte triglyceride lipase expression in human obesity. Am J Physiol 2007;293:E958-964.

-31 Jernas M, Olsson B, Arner P, Jacobson P, Sjostrom L, Walley A, Froguel P, McTernan PG, Hoffstedt J, Carlsson LM: Regulation of carboxylesterase 1 (CES1) in human adipose tissue. Biochem Biophys Res Commun 2009;383:63-67.

32 Okazaki H, Igarashi M, Nishi M, Tajima M, Sekiya M, Okazaki S, Yahagi N, Ohashi K, Tsukamoto K, Amemiya-Kudo M, Matsuzaka T, Shimano H, Yamada N, Aoki J, Morikawa R, Takanezawa Y, Arai H, Nagai R, Kadowaki T, Osuga J-I, Ishibashi $\mathrm{S}$ : Identification of a novel member of the carboxylesterase family that hydrolyzes triacylglycerol: a potential role in adipocyte lipolysis. Diabetes 2006; 55:2091-2097. 
\$3 Grundy SM, Cleeman JI, Daniels SR, Donato KA, Eckel RH, Franklin BA, Gordon DJ, Krauss RM, Savage PJ, Smith SC, Jr, Spertus JA, Costa F: Diagnosis and management of the metabolic syndrome: an American Heart Association/National Heart, Lung, and Blood Institute scientific statement. Circulation 2005;112:2735-2752.

34 Gruson E, Montaye M, Kee F, Wagner A, Bingham A, Ruidavets JB, Haas B, Evans A, Ferrieres J, Ducimetiere PP, Amouyel P, Dallongeville J: Anthropometric assessment of abdominal obesity and coronary heart disease risk in men: The prime study. Heart (British Cardiac Society) 2010;96:136-140.

35 Le Lay S, Krief S, Farnier C, Lefrere I, Le Liepvre X, Bazin R, Ferre P, Dugail I: Cholesterol, a cell size-dependent signal that regulates glucose metabolism and gene expression in adipocytes. J Biol Chem 2001;276:16904-16910.

36 Le Lay S, Ferre P, Dugail I: Adipocyte cholesterol balance in obesity. Biochem Soc Trans 2004;32: 103-106.

37 Buchmann J, Meyer C, Neschen S, Augustin R, Schmolz K, Kluge R, Al-Hasani H, Jurgens H, Eulenberg K, Wehr R, Dohrmann C, Joost H-G, Schurmann A: Ablation of the cholesterol transporter adenosine triphosphate-binding cassette transporter G1 reduces adipose cell size and protects against diet-induced obesity. Endocrinology 2007;148:1561-1573.

-38 Huang ZH, Luque RM, Kineman RD, Mazzone T: Nutritional regulation of adipose tissue apolipoprotein e expression. Am J Physiol 2007;293:E203-209.
39 Gao J, Katagiri H, Ishigaki Y, Yamada T, Ogihara T, Imai J, Uno K, Hasegawa Y, Kanzaki M, Yamamoto TT, Ishibashi S, Oka Y: Involvement of apolipoprotein E in excess fat accumulation and insulin resistance. Diabetes 2007;56:24-33.

40 Arbones-Mainar JM, Johnson LA, Altenburg MK Maeda N: Differential modulation of diet-induced obesity and adipocyte functionality by human apolipoprotein E3 and E4 in mice. Int $\mathrm{J}$ Obes 2008;32:1595-1605.

41 Greenow K, Pearce NJ, Ramji DP: The key role of apolipoprotein $\mathrm{E}$ in atherosclerosis. J Mol Med (Berlin) 2005;83:329-342.

42 Reaven GM: Banting lecture 1988. Role of insulin resistance in human disease. Diabetes 1988;37: 1595-1607.

43 Annuzzi G, Giacco R, Patti L, Di Marino L, De Natale C, Costabile G, Marra M, Santangelo C, Masella R, Rivellese AA: Postprandial chylomicrons and adipose tissue lipoprotein lipase are altered in type 2 diabetes independently of obesity and whole-body insulin resistance. Nutr Metab Cardiovasc Dis 2008;18:531-538.

44 Stafford JM, Yu F, Printz R, Hasty AH, Swift LL, Niswender KD: Central nervous system neuropeptide Y signaling modulates VLDL triglyceride secretion. Diabetes 2008;57:1482-1490.

45 Yagyu H, Lutz EP, Kako Y, Marks S, Hu Y, Choi SY, Bensadoun A, Goldberg IJ: Very low density lipoprotein (VLDL) receptor-deficient mice have reduced lipoprotein lipase activity. Possible causes of hypertriglyceridemia and reduced body mass with VLDL receptor deficiency. J Biol Chem 2002;277:10037-10043.
6 Voshol PJ, Rensen PC, van Dijk KW, Romijn JA, Havekes LM: Effect of plasma triglyceride metabolism on lipid storage in adipose tissue: studies using genetically engineered mouse models. Biochim Biophys Acta 2009;1791:479-485.

47 Goudriaan JR, Tacken PJ, Dahlmans VE, Gijbels MJ, van Dijk KW, Havekes LM, Jong MC: Protection from obesity in mice lacking the VLDL receptor. Arterioscler, Thromb Vascular Biol 2001;21: 1488-1493.

48 Tacken PJ, Hofker MH, Havekes LM, van Dijk KW: Living up to a name: the role of the VLDL receptor in lipid metabolism. Curr Opin Lipidol 2001;12:275-279.

49 Zechner R, Moser R, Newman TC, Fried SK, Breslow JL: Apolipoprotein E gene expression in mouse 3T3-L1 adipocytes and human adipose tissue and its regulation by differentiation and lipid content. J Biol Chem 1991;266:10583-10588.

50 Lumeng CN, Deyoung SM, Bodzin JL, Saltiel AR: Increased inflammatory properties of adipose tissue macrophages recruited during diet-induced obesity. Diabetes 2007;56:16-23.

51 Kim Y, Park T: DNA microarrays to define and search for genes associated with obesity. Biotechnol J 2010;5:99-112.

52 MacLaren RE, Cui W, Lu H, Simard S, Cianflone $\mathrm{K}$ : Association of adipocyte genes with ASP expression: a microarray analysis of subcutaneous and omental adipose tissue in morbidly obese subjects. BMC Med Genomics 2010;3:3. doi: 10.1186/1755-8794-3-3.

53 Li J, Yu X, Pan W, Unger RH: Gene expression profile of rat adipose tissue at the onset of high-fatdiet obesity. Am J Physiol 2002;282:E1334-1341. 